\title{
Rapid Detection and Discrimination of the Three Salmonella Serotypes, S. Pullonum, S. Gallinanum and $S$. Enteritidis by PCR-RFLP of ITS and fliC Genes
}

\author{
Se-Yeoun Cha, Du-Hee Jang, Sang-Min Kim, Jong-Beom Park and Hyung-Kwan Jang ${ }^{\dagger}$ \\ Department of Infectious Diseases and Avian Diseases, College of Veterinary Medicine and Bio-Safety Research Institute, \\ Chonbuk National University, 664-14 Duckjin-dong, Duckjin-ku, Jeonju 561-756, Korea
}

\begin{abstract}
Salmonella enterica serotype gallinarum biovar Gallinarum or Pullorum and Salmonella enterica serotype Enteritidis are the most important diseases in poultry industry. Transitional diagnosis methods of these diseases such as direct isolation and identification by a biochemical test are time consuming with low specificity. In this study, we have focused on the suitable procedure for the rapid and accurate diagnosis of diseases derived from the three Salmonella strains. We initially confirmed Salmonella species by PCR using a specific ITSF/ITSR primer pair instead of biochemical test, and then the PCR-amplified phase 1 flagellin (fliC) using a specific fliCF/fliCR primer pair was digested with a restriction endonuclease, Bpm I and/or Bfa I, to discriminate among $S$. Pullorum, $S$. Gallinarum, and $S$. Enteritidis. We found that these methods could be applied to field isolates of the three Salmonella strains to detect and to discriminate rapidly for convenient diagnosis.
\end{abstract}

(Key words : Salmonella, diagnosis, rapid detection, strain differentiation)

\section{Introduction}

Salmonella enterica serotype gallinarum biovar Gallinarum or Pullorum and S. enterica serotype Enteritidis have been reported to cause major economic problems in poultry industry. S. Gallinarum is responsible for fowl typhoid usually found in chicks (Wray et al., 1996; Shivaprasad, 2003), and S. Pullorum causes pullorum disease that shows white diarrhea as its major symptom and able to infect older chickens (Wray et al., 1996). Moreover, $S$. Enteritidis can be a significant public health problem and can represents the contamination rate of poultry farms (Rampling et al., 1989; Fadl et al., 1995). Therefore, rapid and correct diagnosis of these diseases is more important in blocking and spreading of the outbreaks. However, unfortunately Salmonella strain has the large antigenic diversities over 2,500 serotypes and the conventional methods of the diagnosis require approximately 1 week of diagnosis which includes several steps of growing in selective mediums, conducting biochemical and serological tests or phage typing (Guineess and van Leeuwen, 1978). Moreover differentiation diagnosis between $S$. Gallinarum and $S$. Pullorum responds with low specificity and sensitivity to the conventional methods by showing close relation between biotypes (Cox and Williams, 1976; Ewing, 1986).
In the last years, improved test methods such as restriction fragment length polymorphism (RFLP) of specific genes (Christensen et al., 1992; Kwon et al., 2000), plasmid profiling (Park et al., 1998), ribotyping and pulsed-field gel electrophoresis (Christensen et al., 1992; Olsen et al., 1996) have been reported for the differentiation diagnosis. The purpose of this study is to determine the suitable procedure for the rapid and accurate diagnosis of diseases derived from Salmonellosis in poultry industry. Recently, it was published that detected Salmonellae with almost serovar using internal transcribed spacer (ITS) region by polymerase chain reaction (PCR) method (Chiu et al., 2005). We applied this method in our first step, colony selection, paralleled with biochemical test to confirm comparison of specificity. Then, specific primers were designed to find the phase 1 flagellin $\mathrm{C}$ gene (fliC) for the detection to differentiate these three Salmonella species which $S$. Gallinarum, S. Pullorum, and S. Enteritidis by PCR-RFLP with Bpm I and/or Bfa I.

\section{Materials and Methods}

\section{Bacterial Strains}

Field strains were collected from chicken farms and hat-

\footnotetext{
† To whom correspondence should be addressed : hkjang@chonbuk.ac.kr
} 
cheries and identified by conventional methods as biochemical typing, API-20E. Further biotying was confirmed through the dulcitol fermentation and ornithine decarboxylation test. The control strain used in this study was donated by the National Veterinary Research and Quarantine Service in Korea. All bacteria glycerol stocks $\left(15 \%\right.$, v/v) were kept at $-80{ }^{\circ} \mathrm{C}$ before experiments.

\section{Genomic DNA Extraction}

S. Pullorum ATCC 10398-2, S. Gallinarum ATCC 9184, S. Enteritidis ATCC 13076, E. coli DH5 $\alpha$ and field-isolated Salmonella were cultured with $5 \mathrm{~mL}$ of nutrient broth for 18 hrs. Each of $1 \mathrm{~mL}$ was subjected to extraction of genomic DNA. Briefly, broth cultures were centrifuged for $5 \mathrm{~min}$ at 15,000 rpm and the pellets were resuspended in $100 \mu \mathrm{L}$ of sterilized distilled water. The samples were boiled at $100{ }^{\circ} \mathrm{C}$ for $5 \mathrm{~min}$ and frozen at $-80{ }^{\circ} \mathrm{C}$ for $5 \mathrm{~min}$ in three times and centrifuged for $10 \mathrm{~min}$ at 15,000 rpm. The harvested supernatants were applied to amplify target gene as a template.

\section{Amplification of ITS Gene}

ITS gene primers were designed ITSF (5'-TGCGGCTGGA TCACCTCCTT-3') and ITSR (5'-TATAGCCCCATCGTGTAG TCAGAAC-3') by Chiu et al. (2005). The PCR reaction mixture consisted of $1 \mu \mathrm{L}$ template DNA and $49 \mu \mathrm{L}$ solution containing the follows: $5 \mu \mathrm{L}$ of $10 \times$ PCR buffer $(100 \mathrm{mM}$ Tris- $\mathrm{HCl}$, $\left.15 \mathrm{mM} \mathrm{MgCl}_{2}, 500 \mathrm{mM} \mathrm{KCl}\right), 1 \mu \mathrm{L}$ of $2 \mathrm{mM}$ dNTP, $2 \mu \mathrm{L}$ of ITSF (50 pmol $/ \mu \mathrm{L}$ ), $2 \mu \mathrm{L}$ of ITSR (50 pmol $/ \mu \mathrm{L}$ ), $0.5 \mu \mathrm{L}$ of Taq polymerase (5 U/ $\mu \mathrm{L}$; Enzynomics, Korea), and $38.5 \mu \mathrm{L}$ of sterilized distilled water. Amplifications were performed in a $50 \mu \mathrm{L}$ reaction by using PCR cycler (PTC-220, MJ Research, USA). The cycling conditions were the following: pre-denaturation of $94{ }^{\circ} \mathrm{C}$ for $5 \mathrm{~min}$, and 35 cycling of $94{ }^{\circ} \mathrm{C}$ for $30 \mathrm{sec}, 60{ }^{\circ} \mathrm{C}$ for $30 \mathrm{sec}, 72{ }^{\circ} \mathrm{C}$ for $50 \mathrm{sec}$, and then last extension step at $72{ }^{\circ} \mathrm{C}$ for $7 \mathrm{~min}$. Ten microliter samples of reaction mixtures were analyzed by gel electrophoresis in $2 \%$ agarose gel, dissolved in $1 \times$ TAE (40 mM Tris-Acetate, $1 \mathrm{mM}$ EDTA at $\mathrm{pH}$ 8.3) for $60 \mathrm{~min}$ at $90 \mathrm{~V}$. After staining with ethidium bromide, the amplicons were photographed by Gel Documentation Analyzer (Vilber Lourmat Trance, France).

\section{Amplification of flic gene}

The primer of fliC gene was designed for the differentiation of $S$. Pullorum, $S$. Gallinarum and $S$. Enteritidis. The primers of fliCF (5'- GTCGCTGTCCGACAAACATA-3') and fliCR (5'-G CAGGAGAGAAATGACGCAA-3') were used to amplify 1,500 bp amplicon. PCR master mixture consisted with $1 \mu \mathrm{L}$ template DNA and $49 \mu \mathrm{L}$ solution containing the follows: $5 \mu \mathrm{L}$ of $10 \times$ PCR buffer (100 mM Tris-HCl, $15 \mathrm{mM} \mathrm{MgCl}_{2}, 500 \mathrm{mM} \mathrm{KCl}$ ), $1 \mu \mathrm{L}$ of $2 \mathrm{mM}$ dNTP, $0.25 \mu \mathrm{L}$ of fliCF (50 pmol/ $\mu \mathrm{L}$ ), $0.25 \mu \mathrm{L}$ of fliCR (50 pmol/ $\mu \mathrm{L}$ ), $0.5 \mu \mathrm{L}$ of Taq polymerase (5 U/ $\mu \mathrm{L}$; Enzynomics, Korea), and $42 \mu \mathrm{L}$ of sterilized distilled water. The cycling conditions by using PCR cycler (PTC-220, MJ Research, USA) were the following: pre-denaturation of $94{ }^{\circ} \mathrm{C}$ for $5 \mathrm{~min}$, and 35 cycling of $94{ }^{\circ} \mathrm{C}$ for $30 \mathrm{sec}, 60{ }^{\circ} \mathrm{C}$ for $45 \mathrm{sec}, 72^{\circ} \mathrm{C}$ for $120 \mathrm{sec}$, and then last extension step at $72{ }^{\circ} \mathrm{C}$ for $7 \mathrm{~min} .10 \mu \mathrm{L}$ samples of reaction mixtures were analyzed by gel electrophoresis in $1 \%$ agarose gel.

\section{RFLP Analysis}

The 1,500 bp in size of PCR-amplified fliC gene was extracted and purified by Wizard PCR preps DNA purification system (Promega, USA) following the procedures recommended by manufacturer. The $10 \mu \mathrm{L}$ of purified PCR products were digested and completed for $2 \mathrm{~h}$ at $37^{\circ} \mathrm{C}$ by a restriction enzyme, Bpm I or Bfa I (New England BioLab Co., Beverly, MA, USA). Restriction DNA fragment were separated by electrophoresis in $1 \%$ agarose gel.

\section{Detection of Salmonella in Clinical Samples}

Clinical samples were obtained from suspected chickens by swabbing liver, spleen, heart, lung and kidney in Chonbuk and Kyeongki provinces in Korea. Those samples were following routine growth procedure and applied PCR for ITS gene, and PCR-RFLP for fliC gene, respectively.

\section{Results}

\section{Rapid Detection of Salmonella Species by} PCR-amplified ITS Gene

To establish a rapid detection method of field isolates, we initially performed PCR with a pair of primer (ITSF/ITSR) designed from Salmonellae specific ITS gene and each of DNA templates extracted from the three standard strains of Salmo- 
nellae, S. Pullorum, S. Gallinarum, and S. Enteritidis, a fieldisolated $S$. Typhimurium, and E. coli as a negative control (Fig. 1). As expected, a Salmonellae specific 312 bp fragment was amplified in PCR reaction each of the above Salmonella strains (lanes 1 to 4) but not appeared in E. coli (lane 5). Furthermore, the rapid detection method was applied to a number of field isolates for the discrimination of Salmonellae from Enterobacteriae (Fig. 2). Prior to subject field isolate to be used in experiments, a number of field-isolated Salmonella strains were identified and confirmed as Salmonella species by conventional

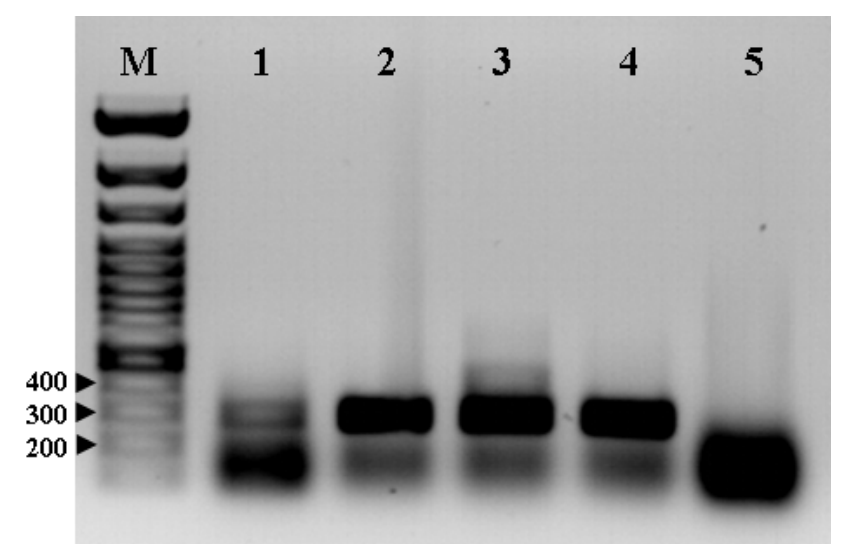

Fig. 1. Specificity of the PCR assay for the detection of Salmonellae using primer ITSF/ITSR. M: 100 bp ladder, lane 1: S. Pullorum ATCC 10398-2, lane 2: S. Gallinarum ATCC 9184, lane 3: S. Enteritidis ATCC 13076, lane 4: $S$. Typhimurium from field isolation, lane 5: E. coli $\mathrm{DH} 5 \alpha$ strain.

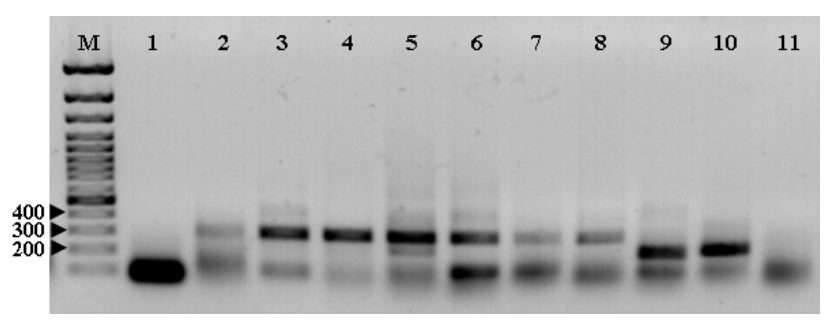

Fig. 2. Applied for the differentiation of Salmonella species from Enterobacteriae among field isolates. M: 100 bp ladder, lane 1: negative control; sterilized distilled water, lanes 2 4: $S$. Pullorum isolates, lanes 5 6: $S$. Gallinarum isolates, lanes 7 8: $S$. Enteritidis isolates, lane 9: E. coli, lane 10: Klebsiella species, lane 11: Citrobacter fruendii. methods using biochemical test. Resultantly, the expected 312 bp fragments were amplified in all of Salmonella strains isolated from field samples (lanes 2 to 8) but not appeared in other Enterobacteriae, such as E. coli, Klebsiella species, and Citrobacter fruendii, respectively (lanes 9 to 11). These results suggested that PCR amplification of ITS gene could preserve the common strains of the above Salmonella strains discussed as in above, which enable the procedure to be conveniently applied to rapid detection and discrimination of Salmonella strains from other Enterobacteria strains in field conditions.

\section{RCR-RFLP Aassay of fliC Genes}

The fliC PCR system resulted to show a unique amplicon of 1,500 bp both standard and field-isolated strains of Salmonellae using a pair of primer (fliCF/fliCR) designed in the present study. Those PCR products were digested with restriction enzyme(s) Bpm I to differentiate $S$. Pullorum from other Salmonella strains, and/or Bfa I to differentiate $S$. Gallinarum and $S$. Enteritidis from other Salmonella strains, respectively (Fig. 3). The digestion patterns of fliC amplicon with Bpm I conferred a definite distinction among Salmonellae including S. Gallinarum (lane 2), only S. Pullorum given two bands of 572 and 928 bp (lane 1), whereas those with Bfa I yielded two bands of 34 and 1,466 bp for S. Gallinarum (lane 3) and 572 and 928 bp for S. Enteritidis (lane 4), respectively. However, no Bfa I site was loca-

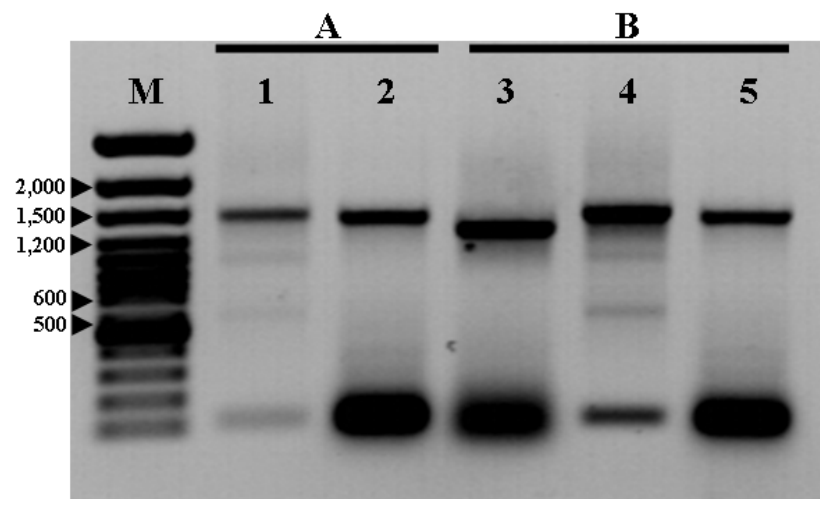

Fig. 3. RFLP assay of PCR-amplified fliC gene (A) digestion with BpmI (B) digestion with BfaI from Salmonellae. M: 100 bp ladder, lane 1: S. Pullorum isolates, lane 2: $S$. Gallinarum isolates, lane 3: S. Gallinarum isolates, Lane 4: $S$. Enteritidis isolates, lane 5: $S$. Typhimurium isolates. 
ted in fliC gene for other Salmonellae including S. Typhimurium (lane 5). These results suggested that RFLP assays using PCR-apmlified fliC genes and two restriction enzymes, Bpm I and Bfa I, could be conveniently used at least for the strain differentiation among $S$. Pullorum, S. Gallinarum, and paratyphoid Salmonellae, such as S. Enteritidis and S. Typhimurium.

\section{Discussion}

Although S. Gallinarum and S. Pullorum can be the serious problems and can cause serious economic losses in poultry industry (Ryll et al., 1996; Shivaprasad, 2003), finding of these diseases by using transitional methods is time consuming and additional tests are closely correlated. Moreover, paratyphoid Salmonellae, such as $S$. Enteritidis and $S$. Typhimurium have been the subject of intensified interest as agents of food-borne disease in humans (Rampling et al., 1989; Tauxe, 1991). Advances in poultry production practices, changes in consumer lifestyles and preferences, and heightened nutritional awareness led the poultry products to be the leading source of animal proteins around the world. Contaminated poultry meats and eggs consistently have been among the most frequently implicated sources of human Salmonella outbreaks. Therefore, the controlling paratyphoid Salmonellae infections in poultry flocks is the important objective from the economic and public health perspectives.

From the perspective of economic losses and control of dissemination of these diseases, it is strongly required to establish a rapid and accurate diagnosis method to minimize the damages. Recently, a number of studies reported to overcome this problem, for example, restriction profiling (Kliger and Grimont, 1993; Dauga et al, 1998), amplify specific genes (Shah et al., 2005), phage typing (Lilleengen, 1952; Guinee and Van Leeuwen, 1978), PCR-RFLP (Kwon et al., 2000; Kisiela et al., 2005) and so on. PCR-RFLP has been applied for the differentiation of Salmonellae for objective result, specificity, sensitivity and advantage of saving economic loss and time.

In this study, we confirmed that there is no difference between PCR methods using a primer pair (ITSF/ITSR) and biochemical test for the detection of Salmonellae (data not shown). Therefore, we could recommend the method as a convenient approach to detect Salmonellae at the first step instead of bio- chemical test. Furthermore, we analyzed restriction enzyme sites of fliC gene with Salmonella species to discriminate S. Purollum, $S$. Gallinarum, and $S$. Enteritidis based on GenBank database. Digestion of amplified fliC gene with BpmI resulted to show 527 and 928 bp only in S. Pullorum, and S. Derby has BpmI restriction enzyme site but RFLP pattern (339 and 1163 bp) is different from $S$. Purollum. In addition, we could differentiate between $S$. Gallinarum (1,466 and 34 bp) and $S$. Enteritidis (928 and 572 bp) by their RFLP difference that the restriction enzyme sites of $B f a I$ in amplified fliC gene exist only in $S$. Gallinarum and $S$. Enteritidis, but not in other Salmonellae.

In the present report, we have proposed a diagnostic procedure focused on the major three Salmonella diseases in poultry industry, which were mainly caused by $S$. Purollum, S. Gallinarum, and $S$. Enteritidis. It is considered to be easily applied as the convenient method of diagnosis according to requirement.

\section{적 요}

양계 산업에서 살모넬라에 의한 질병들 중 가장 중요한 원인체는 S. Gallinarum, S. Purollum, S. Enteritidis로 간주된 다. 생화학적 검사에 의한 직접적인 균 분리-동정과 같은 이들 질병에 대한 종래의 진단법은 많은 시간이 소요되며, 특이성 또한 낮다. 본 연구는 3종의 살모넬라균에 의해 야기 되는 이들 질병에 대한 빠르고 정확한 진단을 위한 효율적 인 진단법에 초점을 두었다. 먼저 종래의 생화학적 검사를 대신하여 새로 고안된 ITSF/ITSR PCR primer를 이용하여 살 모넬라균임을 확인하였으며, 증폭된 phase 1 flagellin (fliC) 유 전자를 $B p m I$ 또는 $B f a I$ 제한 효소로 처리하여 S. Gallinarum, S. Purollum, S. Enteritidis를 상호 용이하게 감별하였다. 이상 의 결과는 3종의 살모넬라균을 효율적으로 진단하기 위해 신속하게 검출하고 감별할 수 있는 유용한 진단법임을 알 수 있었다.

(색인어 : 살모넬라, 진단, 신속검출, 감별진단)

\section{References}

Chiu TH, Chen TR, Hwang WZ, Tsen HY 2005 Sequencing of an internal transcribed spacer region of 16S-23S rRNA gene 
and designing of PCR primers for the detection of Salmonella spp. in food. Int J Food Microbiol 97:259-265.

Christensen JP, Olsen JE, Hansen HC, Bisgaard M 1992 Characterization of Salmonella enterica serotype Gallinarum biotypes Gallinarum and Pullorum by plasmid profiling and biochemical analysis. Avian Pathol 21:461-470.

Cox NA, Williams JE 1976 A simplified biochemical system to screen Salmonella isolates from poultry for serotyping. Poult Sci 55:1968-1971.

Dauga C, Zabrovskaia A, Grimont PA 1998 Restriction fragment length polymorphism analysis of some flagellin genes of Salmonella enterica. J Clinic Microbiol 36:2835-2843.

Ewing WH 1986 Pages 81-318 Edwards and Ewing's Identification of Enterbacteriaceae. 4th ed. Elsevier's Science, New York.

Fadl AA, Nguyen AV, Khan MI 1995 Analysis of Salmonella enteritidis isolates by arbitrarily primed PCR. J Clin Microbiol 33:987-989.

Guiness PA, van Leeuwen WJ 1978 Phage typing of Salmonella. Vol. 11 Pages 157-191 In: Methods in Microbiology. Bergan T, (Ed.) Academic Press, London.

Kilger G, Grimont PA 1993 Differentiation of Salmonella phase 1 flagellar antigen types by restriction of the amplified fliC gene. J Clinic Microbiol 31:1108-1110.

Kisiela D, Kuczkowski M, Kiczak L, Wieliczko A, Ugorski M 2005 Differentiation of Samonella gallinarum biovar Gallinarum from Salmonella gallinarum biovar Pullorum by PCRRFLP of the fimH gene. J Vet Med B 52:214-218.

Kwon HJ, Park KY, Yoo HS, Park JY, Park YH, Kim SJ 2000 Differentiation of Salmonella enterica serotype gallinarum biotype pullorum from biotype gallinarum by analysis of phase 1 flagellin C gene (fliC). J Microbiol Methods 40:33-38.

Lilleengen K 1952 Typing of Salmonella gallinarum and Salmonella pullorum by means of bacteriophage. Acta pathol Microbiol Scand 30:194-202.

Olsen JE, Skov MN, Christensen JP, Bisgaard M 1996 Genomic lineages of Salmonella enterica serotype Gallinarum. J Med Microbiol 45:413-418.

Park KY, Yoo HS, Kim SJ, Park YH 1998 Epidemiology of pullorum disease and characteristics of Salmonella pullorum isolates in Korea. Kor J Vet Res 8:803-810.

Rampling A, Upson R, Ward LR, Anderson JR, Peters E, Rowe B 1989 Salmonella enteritidis phase type 4 infection of broiler chickens: a hazard to public health. Lancet 2:436-438.

Ryll M, Bisgaard M, Christensen JP, Hinz KH 1996 Differentiation of Salmonella gallinarum and Salmonella pullorum by their whole-cell fatty acid methyl ester profiled. Zentralbl Veterinarmed B 43:357-363.

Shah DH, Park JH, Cho MR, Kim MC, Chae JS 2005 Allelespecific PCR method based on $r f b S$ sequence for distinguishing Salmonella gallinarum from Salmonella pullorum: serotype-sepcific $r f b S$ sequence polymorphism. J Microbiol Method 60:169-177.

Shivaprasad HL 2003 Pullorum disease and fowl typhoid. Pages 568-582 In: Diseases of Poultry. Saif YM, (Ed.) 11th ed, Iowa State University Press, Ames, Iowa.

Tauxe RV 1991 Salmonella: A postmodern pathogen. J Food Prot 54:563-568.

Wary C, Davis RH, Corkish JD 1996 Enterobacteriaceae. Pages 9-43 In: Poultry Diseases. Jordan FTW, (Ed.) 4th edn, Saunders Company Ltd, London.

(접수일자: 2008. 3. 17, 채택일자: 2008. 3. 19) 